(a) (1) https://creativecommons.org/licenses/by/4.0/

ARTIGO

\title{
(SEMI)FORMAÇÃO NO CONTEXTO DAS FAKE NEWS E DA PÓS-VERDADE NA SOCIEDADE EXCITADA - DE ADORNO A TÜRCKE
}

\author{
ROBSON LOUREIRO ${ }^{1}$ \\ ORCID: https://orcid.org/0000-0002-8272-5368 \\ EMERSON CAMPOS GONÇALVES ${ }^{2}$ \\ ORCID: https://orcid.org/0000-0002-1355-9976
}

\begin{abstract}
RESUMO: Este artigo problematiza o fenômeno relativo à produção e ao consumo de notícias falsas fake news - no horizonte da crítica à indústria cultural e à Sociedade Excitada na "era da pós-verdade", em que parte considerável das pessoas vicia-se tanto no consumo de estímulos imagéticos como na transmissão ininterrupta de mensagens audiovisuais. A hipótese da pesquisa sustenta que a lógica do mercado avança sobre o labor jornalístico, invade o âmbito privado da vida e institucionaliza, como ethos aceitável, a [re]produção de uma existência fake que faz par e nutre-se na semiformação - Halbbildung. O vigor da análise aposta na reatualização do conceito de formação - Bildung, no âmbito da educação escolar, capaz de contribuir para ampliar a compreensão sobre a lógica de funcionamento da máquina produtora de doses, cada vez mais viciantes, de choques visuais que excitam, entorpecem, minam os sentidos e a capacidade de crítica e autocrítica dos indivíduos.
\end{abstract}

Palavras-chave: Fake news, Formação, Semiformação, Bildung, Halbbildung.

\section{(HALB)BILDUNG IN THE FAKE NEWS AND POST-TRUTH CONTEXT OF EXCITED SOCIETY - FROM ADORNO TO TÜRCKE}

\begin{abstract}
This article problematizes the phenomenon related to the production and consumption of fake news - criticizing the cultural industry and Excited Society in the "post-truth era" in which a considerable part of the public is addicted to both the consumption and the uninterrupted transmition of audiovisual messages. The research hypothesis holds that market logic advances journalistic work, invades the private realm of life, and institutionalizes, as an acceptable ethos, the production of a fake existence that makes itself par and nurtures itself in the semiformation - Halbbildung. The vigor of the analysis is based on updating the concept of Bildung, in the scope of school education, capable of contributing to the broadening of the understanding of the logic of the production machine with its increasingly addictive doses of visual shocks that excite, hinder, undermine the senses and the capacity for criticism and self-criticism of individuals.
\end{abstract}

Keywords: Fake news, Formation, Semiformation, Bildung, Halbbildung.

\footnotetext{
${ }^{1}$ Universidade Federal do Espírito Santo. Vitória, ES, Brasil. < robbsonn@uol.com.br>

${ }^{2}$ Universidade Federal do Espírito Santo. Vitória, ES, Brasil. <professoremersoncampos@gmail.com> Educação em Revista|Belo Horizonte|v.37|e225778|2021
} 


\section{(SEMI)FORMACIÓN EN EL CONTEXTO DE LAS FAKE NEWS Y DE LA POST VERDAD EN LA SOCIDAD EXCITADA - DE ADORNO A TÜRCKE}

RESÚMEN: Este artículo problematiza la producción y el consumo de noticias falsas en el horizonte de la crítica de la industria cultural y la Sociedad Excitada en la "era de la post verdad", donde parte considerable de la gente es adicta al consumo y a la transmisión ininterrumpida de mensajes audiovisuales. La hipótesis sostiene que la lógica del mercado avanza sobre el trabajo periodístico, invade el ámbito privado de la vida e institucionaliza, como un ethos aceptable, la producción de una existencia falsa que se alinea y se nutre en la semiformación. El vigor del análisis se basa en la nueva visualización del concepto de formación en el ámbito de la educación escolar, capaz de contribuir a ampliar la comprensión de la lógica de la máquina de producir dosis cada vez más adictivas de choques visuales que excitan los sentidos y la capacidad de crítica y autocrítica de los individuos.

Palabras clave: Fake news, Formación, Semiformación, Bildung, Halbbildung. 


\section{INTRODUÇÃO}

"A mentira é mais confortável do que a dúvida, mais útil do que o amor e mais duradoura do que a verdade". Tal constatação, apresentada por Gabriel García Márquez em El otonõ del patriarca (1976), surge entre as reflexões de um ditador velho e sem nome, personagem criado por Gabo como alegoria crítica aos regimes ditatoriais da América Latina. Ideia que vai ao encontro do que, um século antes, escreveu Fiódor Dostoiévski: "Mas o ser humano é tão apaixonado pelo sistema e pela conclusão abstrata, que é capaz de fazer-se de cego e surdo somente para justificar sua lógica" (DOSTOIÉVSKI, 2018, p. 33). A assertiva, pronunciada pelo narrador-personagem do romance Notas do Subsolo, publicado originalmente em 1864, é uma das inúmeras críticas de Dostoiévski direcionadas aos 'homens de ação direta' do seu tempo, isto é, aos indivíduos semiformados da Rússia Czarista (1721-1917). Guardadas as ressalvas, em função dos dois saltos históricos, de igual maneira no que diz respeito aos regimes objetivos e subjetivos de produção social da existência, pode-se facilmente identificar, nos 'homens de ação direta' no atual Zeitgeist, uma tendência de sedução e/ou simulacro semelhante pelo consumo de notícias falsas - fake news.

A produção, reprodução e o consumo de fake news, em especial por meio das redes sociais online da internet, podem ser concebidos com uma busca de adequação à realidade exterior. Ainda que com olhos e ouvidos abertos, as pessoas estão entorpecidas e carecem de uma educação dos sentidos que lhes possibilitem sair do recôndito subsolo da psique, com seus sedimentos reprimidos pelo ego fraco, cujas escolhas abstratas pouco podem ser justificadas pela razão. Caso contrário, a despeito de todos os mecanismos de fact checking (checagem de fatos) disponíveis, como explicar, por exemplo, a ampla adesão de eleitores ao boato veiculado por um vídeo (que obteve mais de 9 milhões de visualizações na Internet) sobre uma mamadeira erótica, em formato de pênis (POMPEU, 2018), que teria sido distribuída às crianças pelo Governo (2014-2016) de centro-esquerda? Essa teria sido uma das justificativas que supostamente definiu a decisão de inúmeros eleitores, por terem escolhido para presidente, um representante de extrema-direita nas eleições presidenciais de outubro de 2018, no Brasil.

Por trás do absurdo discursivo, que surge como imperativo dentro de cada tentativa de se legitimar aquilo que a própria consciência atesta como falso, existe uma considerável dose de cinismo retratado pela literatura existencialista de Dostoiévski, aqui aludida apenas como um convite para o debate que segue.

Faz algum tempo a verdade tem sido um artigo démodé. Atualmente, pelo menos no campo da política, ela tem estado fora de moda. Se é que algum dia esteve, pois a demagogia e o cinismo sempre foram bem atuantes nesse métier. O que assusta, talvez, é que a relação coletiva com o valor da verdade parece ter piorado nos últimos anos (HARSIN, 2018). A pós-verdade foi declarada a palavra do ano de 2016. Em relação a 2015, seu uso aumentou cerca de 2.000\% (OXFORD ONLINE). Este dicionário a define como tudo que é relativo ou denota circunstâncias nas quais apelos à emoção e convicção pessoal são mais influentes na formação da opinião pública do que os fatos objetivos. Dois eventos políticos configuram-se como emblemáticas evidências da afirmação de que vivemos em uma era de pós-verdade: a vitória na campanha Leave, no referendo do Brexit - saída da Inglaterra da União Europeia - e a bemsucedida corrida para a presidência de Donald Trump - EUA - (HARSIN, 2018; HÄNSKA; BAUCHOWITZ, 2017) e Jair Bolsonaro - Brasil. A pós-verdade tem tanto a ver com a ideia de falta de crença justificada (como se o texto fosse autopoiético e a realidade construída por ele), como com a não necessidade de referência empírica (evidências) - a honestidade da informação.

Pautado em uma hermenêutica orientada pela filosofia social da teoria crítica da sociedade, o escopo do artigo é problematizar a estreita relação das fake news/pós-verdade com a superestrutura marcadamente dominada pela indústria cultural que não para de danificar o momento formativo dos indivíduos (ADORNO, 2010; ZUIN, 2001).

Interessa compreender o que leva as pessoas a, mesmo de olhos e ouvidos abertos, comportarem-se como se fechados estivessem para fenômenos sociais que dizem respeito a existência de todos. Seria intencional a recusa da visão e da audição? Ou o entorpecimento dos sentidos é o resultado da evolução "natural" da sociedade do espetáculo (DEBORD, 2003)? Em busca de respostas a essas questões, recorre-se ao estudo das fake news, que são analisadas a partir da hipótese de que, 
enquanto discurso, integram um fenômeno cuja gênese residiria nos processos de semiformação (Halbbildung) fomentados pelos operadores da indústria cultural. Parte-se da premissa de que a consolidação de uma sociedade excitada, viciada em estímulos/choques audiovisuais (TÜRCKE, 2010; 2016), é decisiva para o estabelecimento das fake news como ethos aceitável da esfera pública hodierna. E é justamente a partir dessa premissa que se toma a defesa de que, ao mencionar e analisar criticamente as condições de formação (ou semiformação) nesta sociedade, discute-se, por conseguinte, um problema e um campo que é - sobremaneira - educacional, afinal, nos termos de Adorno:

[...] a própria organização do mundo em que vivemos e a ideologia dominante - hoje muito pouco parecida com uma determinada visão de mundo ou teoria -, ou seja, a organização do mundo converteu-se a si mesma imediatamente em sua própria ideologia. Ela exerce uma pressão tão imensa sobre as pessoas, que supera toda a educação. Seria efetivamente idealista no sentido ideológico se quiséssemos combater o conceito de emancipação sem levar em conta o peso imensurável do obscurecimento da consciência pelo existente (ADORNO, 1995, p. 144).

O artigo está dividido em três seções e as considerações finais. Na primeira, abordam-se o conceito de formação - Bildung - e semiformação - Halbbildung. Em seguida, problematiza-se, por meio da teoria crítica da sociedade, a influência dos media na formação que acontece no âmbito da esfera pública, a partir do conceito de jornalismo moderno. No terceiro item, apresentam-se aspectos da Filosofia da Sensação (TÜRCKE, 2010) como mediadora da reflexão mais adequada à compreensão dos desafios impostos pela liberação do polo emissor e a consequente proliferação das fake news em uma sociedade que supersatura, suspende e formata os sentidos. Por fim, busca-se responder como e em que medida a transferência da pressão de mercado para a vida privada contribui para a institucionalização de uma [re]produção fake da própria existência como ethos aceitável e aparentemente necessário, sendo o debate desse tópico a principal contribuição deste trabalho, a partir dos movimentos teóricos supramencionados.

\section{FORMAÇÃO (BILDUNG) E SEMIFORMAÇÃO (HALBBILDUNG) NO CONTEXTO DA INDÚSTRIA CULTURAL}

A considerar como positiva a resposta de Habermas (2000) relativa à pergunta sobre o fim do projeto da modernidade, dentre as várias implicações, estaria o fato de que a humanidade teria entrado em uma época inteiramente nova - pós-moderna (?) - e já seriam demodê tanto o conceito de Bildung como sua associação com a subjetividade, a autoconsciência e a autodeterminação. De fato, a tese sobre o fim da modernidade esteve presente no debate acadêmico em parte da década de 1980, tendo se intensificado nos anos 1990, com sinais de arrefecimento, ao menos em determinados campos das humanidades, no início deste século. A discussão envolveu autores (LYOTARD, 2000; BAUDRILLARD, 1991; 1996) que tanto celebraram o fim da modernidade e pronunciaram o início de uma nova era - "condição pós-moderna" -, como aqueles (SOKAL; BRICMONT, 2010; ANDERSON, 1999; WOOD, 1999; EAGLETON, 1999; NANDA, 1997) que denunciaram e criticaram a fragilidade teórica das teses pós.

No campo da educação, em especial no Brasil, pesquisadoras como Lopes (2013), Gonçalves e Borba (2009) mantêm-se saudosistas e defensoras de teses que mais lembram ficções filosóficas distópicas elaboradas por autores (LYOTARD, 2000; RORTY, 1994) que já fizeram a mea culpa (LYOTARD, 2014a; 2014b; RORTY, 1999) para tentarem se afastar da criatura - o pós-moderno - por eles próprios inventada. Lopes (2013) insiste no discurso que depõe contra teorias que fundamentam projetos políticos que sempre lutaram por uma sociedade sem poder, sem classes, sem desigualdades e, na medida razoável do possível, reconciliada consigo mesma. Por mais que as evidências sinalizem para o contrário, essa autora continua a descrever o cenário atual de pós-moderno, também denominado de "modernidade líquida, fluida, instável, tardia". Ela afirma que os estudos de corte pós-crítico - o que inclui a apropriação de estudos pós-estruturais, pós-coloniais, pós-modernismo, filosofia da diferença, neopragmatismo, multiculturalismo, estudos de gênero, estudos feministas, nova história (só para citar alguns) - não têm sido hegemônicos, in totum, no campo educacional brasileiro, mas o são no âmbito do Grupo de Trabalho 
(GT) Currículo, da Associação Nacional de Pós-Graduação e Pesquisa em Educação - Anped - (LOPES, 2013, p. 8). Na mesma direção, Gonçalves e Borba (2009) afirmam que o educando contemporâneo é reflexo de uma sociedade pós-moderna.

Dentz (2015) observa que a teoria pós-crítica já é hegemônica em inúmeras áreas da educação, o que se comprova pelo fato de haver uma denominação específica que caracteriza o grupo de pesquisadores a ela vinculados. Para designar o conjunto das perspectivas pós-críticas que passaram a ocupar a produção teórica no campo da educação, Severino (1999) cunha o termo arqueogenealogia em alusão às vertentes da filosofia da educação que privilegiam temas como cotidiano, amor, desejo, relação pessoal, intimidade, singularidade, o imaginário, o inconsciente, o emocional e o corporal; questiona a centralidade do sujeito; rejeita o discurso filosófico iluminista da modernidade que segundo os póscríticos assume a "[...] forma de metanarrativas pretensiosas e prepotentes que impõe leis à história, que é pura contingência” (SEVERINO, 1999, p. 289). Enquanto tendência de filosofia da educação, a corrente arqueogenealógica sobrepõe a dimensão estética (estetização da realidade), entendida “[...] como vivência no plano da sensibilidade geral do indivíduo, mente e corpo, lugares de uma economia desejante" (SEVERINO, 1999, p. 290), em detrimento da formação de um sujeito ética e livremente responsável (CHAUÍ, 2000).

De forma mais agressiva, nas últimas décadas do século XX e, com menos vigor, nos últimos vinte anos desse início do XXI, tem sido recorrente a crítica de autores pós que insistem em considerar ultrapassada qualquer tipo de política pública no campo da educação fundamentada no conceito de formação (Bildung) gestada no contexto do Iluminismo. Este é o caso de Lyotard (2000, p. 4), ao afirmar que cairia cada vez mais em desuso o princípio segundo o qual a aquisição do saber é indissociável da formação do espírito, e mesmo da pessoa.

Apesar de não se configurar como um sistema filosófico com unidade teórica, pode-se considerar que as teses dos autores "do pós-moderno" fazem parte de uma agenda (MORAES, 1996; 2004; WOOD, 1999) da qual inserem-se pensadores pós-estruturalistas, pós-críticos bem como aqueles vinculados ao multiculturalismo, neopragmatismo, pós-colonialismo, construcionismo social cujas ideias centrais podem ser assim resumidas: negação da existência de uma realidade objetiva independente da percepção humana - o mundo objetivo não passa de uma construção linguística; afirmação de que o conhecimento é filtrado por prismas de gênero, raça, etnia e outras variáveis, mas dificilmente pela classe social; rejeição da ideia de verdade, que é substituída por noções de perspectiva e posicionamento; defesa de que a linguagem é instável/não confiável e que a ideia de racionalidade, autonomia e a própria ciência moderna são narrativas (ou metanarrativas) da modernidade; ataque à ideia da possibilidade do consenso que resulta na impossibilidade da ética como caminho para o diálogo consensual - incomensurabilidade dos valores morais; desprezo a categorias como totalidade, universalidade, contradição, dialética, ideologia - guerra contra a tradição marxista e à teoria crítica em geral; ruptura com as fronteiras do conhecimento - a ciência e a história são tão narrativas quanto a literatura e a mitologia; estetização da vida e hipervalorização da cotidianidade fundada nas diferenças anárquicas, desconectadas e inexplicáveis; ênfase na instabilidade da linguagem - desconstrucionismo como forma de análise textual cuja aplicação vale tanto para a literatura como para a história, arquitetura e as ciências humanas, em geral; relativismo extremo - impossibilidade de discernir a objetividade e intenção do autor, pois tudo é tudo e nada é nada e qualquer coisa pode significar qualquer coisa; crítica à ideia de que haja uma leitura óbvia ou de senso comum - tudo tem uma infinidade de significados. Em outros termos: não há verdade (KAKUTANI, 2018; GRENZ, 2008; ANDERSON, 1999; WOOD, 1999; EAGLETON, 1999; 1993; NANDA, 1997).

Um dos primeiros intelectuais a enfrentar esse debate, ainda que com flertes ardentes com a virada linguística de matiz pós-metafísica, foi Jürgen Habermas (2000). No final do seu Discurso filosófico da modernidade, ele sugere que esta é um projeto inacabado; considera que o mundo da vida racionalizado continua sendo fundamento para as esferas públicas autônomas; que o potencial de interpretação próprio da cultura, da ciência e da filosofia, para o esclarecimento de ideias jurídicas e morais estritamente universalistas continuam mais relevantes do que os conteúdos de experiências radicais da modernidade estética (HABERMAS, 2000, p. 507). Aqui, o autor parece subestimar as teorias estético-literárias e, talvez à sua revelia, cria um obstáculo para o projeto de uma formação ampla, no caso da instituição 
escolar, mediada pelas humanidades, justo o que há de mais potente a nutrir o conceito da Bildung (BOHLIN, 2013).

Contudo, a estética nunca representou, tal como Habermas (2000) parece sugerir, uma fuga das discussões "sérias", tampouco na modernidade ela se reduziu ao mero juízo de gosto relativo às artes (esteticismo). Desde sempre, esteve ligada à moral, à política, à educação, à teoria do conhecimento, pois não há como escapar do debate sobre a ética, a moral, a política, a verdade, a ideologia (EAGLETON, 1993). Na Carta II d' A educaşão estética do homem, Schiller (1994, p. 26), considera que "[...] a arte é filha da liberdade e quer ser ligada pela necessidade do espírito, não pela privação da matéria [...] para resolver na experiência o problema político, é necessário caminhar através do estético, pois é pela beleza que se vai à liberdade". Também as contribuições de Fichte, Goethe, Humboldt, Schlegel, Hölderlin, Nietzsche referendam, de forma documental, aquela observação de Schiller (WEBER, 2006). Os autores que lidam com o conceito de Bildung demonstram um esforço sempre renovado em acolher problemas de procedências variadas, o que não significa aderir a simplificações trazidas pelo ecletismo, quando se considera sua pluralidade, mas, acima de tudo, crítica que transcende aos "[...] elementos objetivos, pois, formar-se - conforme pensam Goethe e Nietzsche - significa pensar contra si próprio" (WEBER, 2006, p. 129).

Ainda que não haja total congruência entre as teses, há ao menos um ponto em comum com a ideia de se compreender a Bildung como um ato de pensar contra si próprio e o argumento de Hans-Georg Flickinger (2011), para quem a Bildung deve reconsiderar o sentido das diretrizes iluministas na educação, com destaque para a postura autorreflexiva por parte dos operadores da educação escolar, pautados em uma ética do reconhecimento. Esse autor critica a orientação exclusivamente profissionalizante da formação, o excesso de regras burocráticas, a perda de uma cultura do conflito e a normatização do comportamento social adestrado e avesso à contestação do estabelecido. A escola e seus agentes responsáveis, segundo Flickinger, carecem da falta de disposição para repensar seus pilares, pois estão alinhados com a racionalidade técnico-instrumental e utilitarista. Para ele, a ética do reconhecimento exige uma predisposição ao comportamento sem pudor narcísico, que deixe transparecer nossas próprias falhas e fraquezas. É um movimento de aceitação do não idêntico na sua alteridade, bem como um desafio à própria autoimagem do educador rumo a uma responsabilidade que pode direcioná-lo para a autorreflexão crítica (FLICKINGER, 2011).

Mesmo com toda a fragilidade, corrosão e danificação da vida - em todos os níveis da existência - característicos da sociedade capitalista, pode-se pensar que a íntima relação entre educação e Bildung está no ideal de transformação social capaz de criar as condições de possibilidade para produzir e garantir a justiça social baseada na liberdade de cada indivíduo, de forma autônoma, escolher seus próprios caminhos (BANDEIRA; OLIVEIRA, 2012). Na trajetória moderna, em especial no contexto no qual a Bildung submete-se à lógica do capital e seu deus mercado, cujo resultado é um reducionismo empobrecedor das relações sociais, a formação acaba por se converter em semiformação - Halbbildung (ADORNO, 2010). Com isso, tanto no aspecto cognitivo quanto no afetivo, o sistema educacional formal tende a submeter o indivíduo a uma passividade em face de processos semiformativos que o impelem ao conformismo e à falsa ideia de felicidade obtida pelos bens de consumo (BANDEIRA; OLIVEIRA, 2012) dispostos pela indústria cultural.

A referência à Bildung, portanto, remete à sua antagonista - Halbbildung (semiformação) -, razão pela qual Zuin e Zuin (2017) consideram que a reflexão crítica sobre o modo como ela se renova, na sociedade de cultura digital, ou Idade Mídia (ZUIN; GOMES, 2019) torna-se fundamental para que se possa elaborar considerações sobre seu (da Bildung) renascimento.

Substantivo feminino da língua alemã, na raiz da palavra encontra-se Bild (imagem, forma, contorno, quadro) presente no verbo Bilden (formar, criar). Bildung pode então ser traduzida por formação, criação, cultivo, educação, cultura e por isso mantém forte inspiração e proximidade com o conceito de Paideia (Antiguidade grega), no sentido de uma experiência na qual o indivíduo, ao menos em tese, seria capaz de tornar o humano mais próximo daquilo que adere ao projeto que se tem de humanidade naquele contexto (SUAREZ, 2005).

Se o projeto da modernidade é ainda inacabado (HABERMAS, 2000); se a sociedade contemporânea permanece capitalista (WOOD, 1999), seria razoável atualizar o conceito de Bildung, 
rebento e herdeiro da tradição iluminista e objeto de controvérsias em torno da realização do seu projeto? A vitalidade desse conceito deve-se muito ao acolhimento da ética, da educação, da estética e da política, o que a fez constituir-se como ponto máximo de realização de uma filosofia da educação atualizada para debater os impasses, incongruências e disparates da realidade. Fundada no período do Iluminismo, momento de forte crítica (e autocrítica) aos valores do Ancien Régime europeu, a maioria dos filósofos fortaleceu, no conceito de Bildung, a ideia de autodeterminação e autorregulação do sujeito, no âmbito da esfera pública, em detrimento da heteronomia da sociedade feudal. O uso original do conceito tem um porquê: associa-se à ideia de formação concebida como experiência (Erfahrung) que se dá no mundo atravessado pelas possibilidades que os indivíduos têm, em uma sociedade "livre", de conhecer e incorporar as idiossincrasias próprias das manifestações da cultura do não idêntico, em complemento, mas sem excluí-la, da educação estritamente formal (Erziehung) que acontece no espaço escolar. Isso porque, em alemão, Bildung é um termo que faz par, mas não se reduz nem à Erziiehung (educação escolar), tampouco à Ausbildung (instrução técnica). Esse último mais atrelado ao instrumentalismo a que comumente se reduz o aprendizado mais técnico-profissionalizante.

Antes mesmo do conceito indústria cultural ter sido formulado (HORKHEIMER; ADORNO, 1985), Nietzsche (2007) havia descrito as duas principais tendências ou orientações da cultura (Bildung) e da educação (Erz̧iehung) no contexto alemão da segunda metade do século XIX. Correntes aparentemente opostas, nefastas nos efeitos e unidas nos resultados (NIETZSCHE, 2007), cujas características, em 1872, delineavam as orientações da política pública para a educação alemã: a tendência à extensão máxima da cultura, que, segundo ele, pretendia estendê-la (massificação) para círculos cada vez mais amplos, e a tendência à redução, que resulta no enfraquecimento da educação, pois exigia que a cultura abandonasse as suas ambições mais elevadas, nobres e sublimes.

A extensão da educação, por meio da criação de mais estabelecimentos de ensino, representava, para Nietzsche, o fortalecimento do principal dogma da economia política da época, cuja lógica podia ser resumida na ideia de que o acúmulo de conhecimento e cultura aumentam a produção e a necessidade, concebidas como máximo de felicidade possivel. O objetivo e o fim da educação passaram a ser a utilidade, mais exatamente o lucro, o maior ganho de dinheiro possível; formar homens comuns, ordinários, correntes, “[...] um pouco no sentido em que se fala de uma 'moeda corrente - quanto mais homens correntes, mais feliz seria o povo; uma cultura rápida que permitisse alguém ganhar dinheiro, e também fundamentada, para se ganhar muito dinheiro [...]” (NIETZSCHE, 2007, p. 62).

A outra tendência, redução da cultura e da educação, expressava tanto a aversão quanto à tecnificação das humanidades. Essa redução, segundo Nietzsche (2007), podia ser sintetizada no fortalecimento e consagração da figura do erudito especializado, uma espécie de operário de fábrica, cuja atividade demanda incrível virtuosidade, mas que se reduz à fabricação de determinados tipos específicos de objetos ou máquinas, ao longo da vida. Para o filósofo, esse processo distancia os eruditos da verdadeira cultura. E é justamente o jornalismo o ponto de confluência das duas tendências: ampliação e redução da cultura. O jornal a substitui. Aquele que tem pretensões à cultura habitualmente se apoia "[...] nesta trama viscosa que cimenta as juntas de todas as formas de vida, de todas as classes sociais, de todas as artes, de todas as ciências. É no jornal que culmina o desígnio particular que nossa época tem sobre a cultura: o jornalista, o senhor do momento [...]", lócus da semiformação - Halbbildung (NIETZSCHE, 2007, p 65). Isso porque, no final do século XIX, alguns jornais evocavam uma linguagem degradada.

No contexto (Universidade de Basel, 1872) em que Nietzsche (2007) escreveu suas conferências (Sobre o futuro dos nossos estabelecimentos de ensino), havia inúmeros exemplos que atestavam a corrupção da língua alemã por parte dos jornalistas que disseminaram a "doença" linguística dos alemães, que atingira proporções epidêmicas: as pessoas passaram a escrever e falar sem se importarem com as regras gramaticais; houve uma proliferação dos neologismos jornalísticos; intensificou-se o abuso de expressões idiomáticas; descaso com o uso correto da declinação e as conjunções alemãs; o mau uso de adjetivos etc. (REITTER; WELLMON, 2016).

Em síntese, ainda que flerte com a verve aristocrata do romantismo tardio, pode-se traduzir a crítica de Nietzsche como sendo uma preocupação vinculada à perda da experiência (Erfahrung), cujo 
lugar do professor erudito, já naquele contexto, teria sido ocupado pelo jornalista especialista (NIETZSCHE, 2007).

No século XX, Adorno (2010), expoente da teoria crítica da sociedade, debruçou-se tanto sobre o conceito de Bildung como o de Halbbildung. Para ele, a crise da formação cultural não poderia se reduzir a um simples objeto da pedagogia - que se ocuparia diretamente disso. Os sintomas do colapso da formação, escreve Adorno (2010), em Teoria da semiformação, estão por toda parte, mesmo no meio de pessoas supostamente cultas. O problema, portanto, não se esgota com as insuficiências do sistema educativo, tampouco por métodos de educação criticados por gerações.

No nível das relações transcorridas na cotidianidade, o mais comum é correlacionar, de forma direta e mecânica, a apropriação dos bens culturais com civilização, como se fosse uma equação matemática: quanto mais cultura, mais civilizado. Contudo, Adorno enfatiza a necessidade de dessacralizar a própria ideia de cultura e ele cita o contexto da Alemanha nazifascista, no qual foi considerável o número de pessoas que usufruiu e se apropriou dos bens culturais e ainda assim encarregou-se da "práxis assassina" do nazismo (ADORNO, 2010). Isso teria a ver não somente com uma dissociação da consciência, mas com o objetivo daqueles bens, à própria humanidade e à totalidade do que lhe diz respeito, pois não há como se separar das coisas humanas. $\mathrm{Na}$ avaliação de Adorno, a formação que disso se esquece, que descansa em si mesma e se absolutiza, acaba por se converter em semiformação, pois, ao menos em tese, o objetivo da Bildung é tornar as pessoas aptas para enfrentarem a realidade em uma sociedade racional, e com liberdade existirem em uma sociedade livre (ADORNO, 2010).

O sonho de formação cultural, que impõe a libertação da imposição dos meios, bem como da estúpida e mesquinha utilidade, escreve Adorno (2010), transforma-se em apologia do mundo organizado. Apesar de toda ilustração e informação que se difundem, a formação cultural na sociedade administrada (capitalista) converte-se em semiformação (ADORNO, 2010). Daí a importância de se considerar o caráter dialético (contraditório) da Bildung, que diz respeito tanto ao aspecto de autonomia e emancipação dos sujeitos, como também o momento da adaptação integrativa. Esses dois elementos formam uma dinâmica cuja tensão entre os polos é um processo do qual não há como se livrar. O momento de integração é importante, pois alguma adaptação é necessária. O problema emerge quando dessa tensão, o polo positivo (submissão à realidade dada, adaptação) sobrepõe-se ao elemento negativo (liberdade, autonomia do sujeito) e torna-se fundamento de uma práxis que tende a ser hegemônica. Nos casos em que a cultura é reduzida ao conformar-se à vida real, ela destaca unilateralmente o momento de adaptação e impede que as pessoas se eduquem umas as outras (ADORNO, 2010).

Adorno (2010) argumenta que a semiformação diz respeito a uma estratégia da burguesia para permanecer no domínio e que a indústria cultural é a ideologia do sistema; ela dificulta tanto a formação cultural autêntica quanto uma educação não determinada pelos esquemas da indústria cultural. O oposto da formação cultural é a não cultura. Nesta, há uma predisposição ao saber; alguma ingenuidade no não saber que permite uma relação imediata com os objetos e pode elevá-los a um sentir/pensar/agir mais críticos porque capaz de elevar-se acima da obviedade ordinária da existência. O momento de não cultura contém um potencial que antecede a cultura propriamente dita (que carrega o conflito entre adaptação e autonomia). A Bildung seria a fase de contestação da dimensão meramente positivo-afirmativa; elevação do caráter negativo/emancipador da cultura.

Ordinária é a relação do semiformado com a dimensão simbólica a que tem acesso quase que unicamente por meio do consumo dos bens culturais que circulam no livre mercado regulado pela indústria cultural. Esta, quase sempre consegue fazê-lo acreditar que é um ser autônomo, culto, integrado e plenipotente em face do todo. No entanto, a semiformação reforça o processo de alienação individual e coletiva. Ela não se confina apenas no espírito, mas também adultera a vida sensorial. Na avaliação de Adorno (2010), ao se julgar detentor do saber, o sujeito acaba por dificultar, por meio de um qualificado mecanismo de defesa, a ampliação daquilo que supõe saber.

É o que acontece, por exemplo, na relação com a chamada cultura erudita. Esta requer do fruidor uma atenção desacelerada, concentrada nos detalhes presentes nas suas diversas formas de expressão. Tal comportamento é, de imediato, considerado difícil e inútil pelo consumidor entusiasta dos produtos hegemônicos da cultura industrial. Na racionalização dessa justificativa, ou mecanismo de defesa do sujeito semiformado, ao invés de aceitar e reconhecer a complexidade imanente da arte erudita, ele 
prefere considerar que seu acesso é restrito ao reduto da elite. Implícita a essa racionalização está o conceito de ressentimento - resultado da exclusão do acesso àqueles bens culturais. Com isso, o cidadão cliente tende a atacar, muito violentamente, tudo que é rotulado de erudito, porque ele considera que em nada tem a ver com a sua realidade. Nessa roda viva, contínuo é o consumo dos produtos do clichê, com suas versões sempre facilitadas (pasteurizadas) da cultura erudita em geral.

Ao invés de uma ampliação da sensibilidade, a dimensão estético-sensorial do indivíduo semiformado é acometida por um quase que generalizado empobrecimento dos sentidos (ADORNO, 1991). A pobreza da experiência (BENJAMIN, 1994a), típica da sociedade administrada - capitalista -, na qual o capital e a burguesia que o protegem são sacralizados (ADORNO, 2010), induz à formação de sujeitos fragilizados porque, quando hipersensibilizados com choques audiovisuais (ZUIN; ZUIN, 2017; TÜRCKE, 2010), têm também os sentidos anestesiados.

Por mais que em toda época da história as sociedades em geral viveram uma espécie de controle administrativo, que não dizia respeito apenas ao aspecto funcional da vida pública, mas, principalmente, da administração dos sentidos, da sensibilidade dos indivíduos, talvez seja acertado afirmar que essa dinâmica da sociedade administrada se exacerbou no último século. Essa ideia remete ao conceito de mundo administrado, cuja principal característica é a fetichização da técnica, a coisificação que danifica e espolia as relações humanas (RUSCHEL, 1995). É nesse sentido que para Adorno (2010) a semiformação é o espírito conquistado pelo caráter de fetiche da mercadoria: a forma dominante da consciência atual. Momento no qual a experiência é substituída por momentos que, no caso da sociedade do espetáculo (DEBORD, 2003), tende a se resumir a cliques de informações fugazes (TÜRCKE, 2010). Cada mensagem acessada motiva uma espécie de programação oculta - obsolescência da informação - que instantaneamente impele o consumidor a suplantá-la e vê-se impulsionado a acessar outra suposta novidade: que é o sempre mesmo.

A existência fragmenta-se nesses instantes de consumo desconexos. Ao invés de uma duração do tempo - temps durée -, da conexão de um viver em si relativamente uníssono que resulta na capacidade de julgar, põe-se um 'É isso' sem julgamento (ADORNO, 2010). A semiformação debilita a relação que se tem com o tempo. Ela enfraquece a memória, abarrotada de mensagens produtoras de um vazio da memória (ADORNO, 2010). Essa ideia compõe com a distinção que Walter Benjamin faz entre os conceitos de Erfahrung (experiência) e Erlebnis (vivência). Esta representa a vivência apressada e imediata do indivíduo supostamente pleno, inflacionado de informações compartilhadas em pseudocomunidades que o isolam de si e da própria realidade - alguém que passa pela vida como espectador, que apenas reage a estímulos (RAMOS-de-OLIVEIRA, 1998, p. 31). A Erfahrung, por sua vez, remete à experiência que se sedimenta e se prolonga em um processo formativo porque reflexivo e emancipador: "Tem Erfahrung quem é capaz de extrair da vida uma experiência, uma compreensão; trata-se de alguém capaz de sentir e de expressar a si mesmo essa vivência; de alguém que extrai da experiência pessoal seu sumo à luz do legado cultural", uma relação de mútuo enriquecimento (RAMOS-de-OLIVEIRA, 1998, p. 31). Aprisionada nos limites da vivência, a semiformação acomete a relação do sujeito consigo mesmo e com a realidade-mundo. Por ser um incentivo a não reflexão, ela apenas limita a capacidade de percepção enfastiada de informações que tanto excitam como anestesiam os sentidos, dos quais fazem parte o entendimento e a razão.

Nesses termos, felizes seriam os bem-adaptados à lógica desse sistema fundamentado em mecanismos de projeção e identificação com formas de ser e estar no mundo, de um modelo de existência que incentiva uma vida destituída do trabalho essencial que reside na atitude crítico-reflexiva (ZUIN; ZUIN, 2017) que dá início à ruptura da escravidão à qual se é submetido pelos inúmeros programas (cada aparelho carrega um programa ao qual o usuário deve se submeter) que induzem ao desejo de integrar-se e a qualquer custo fazer ser mais um na massa. De forma quase sempre incontestável, o semiformado tende a aderir a grupos que espelham a imagem e semelhança desse modelo, cujo propósito é banir tudo que esteja fora dos ditames do esquema previamente engendrado pela indústria cultural, cujo escopo não é separar, mas unir, de modo que "ninguém escape" de suas garras e de suas ideias universais (ADORNO; HORKHEIMER, 1985, p. 101).

Ao promover uma falsa reconciliação entre o todo e o particular, a indústria da cultura busca travestir de natureza todas as suas manifestações. Sem perceber, os indivíduos incorporam 
comportamentos como se eles sempre estivessem ali. Como em um processo hipnótico ou mesmo do vício em face do consumo de alucinógenos, o mundo virtual veiculado pelos aparatos dos media televisão, internet e "suas" social media (Twiter, Facebook, YouTube, Instagram, Whats App etc.) dificulta que seus consumidores lhes direcionem qualquer crítica. Ao naturalizar seus padrões universais, a indústria cultural não apenas forma indivíduos fracos, no sentido nietzschiano, como promove a alienação desses frente ao mundo: tão logo apareça a oportunidade, há uma forte tendência à renúncia a toda singularidade, em nome de um conceito universal que promete liberdade, igualdade e felicidade, mas cuja ideologia é a própria chave da prisão.

A mercantilização dos bens simbólicos visa à integração e reconciliação forçada entre os grupos sociais desiguais entre si. O sistema de produção de mercadorias culturais é pautado na falsa promessa de que a massificação da cultura possibilita a formação de indivíduos autônomos e uma coletividade emancipada (ZUIN, 2001). Não obstante, um dos principais recursos da engenharia de produção da cultura industrial é o sequestro do esquematismo, no sentido kantiano, destinado aos sujeitos (ADORNO; HORKHEIMER, 1985; DUARTE, 2003). Não resta nada mais a ser apreendido que já não tenha sido discutido e digerido pelos operadores dos mass media. Tudo é previamente elaborado de tal forma que o público é desacostumado de refletir por conta própria. As aparentes críticas, possibilidade de escolha e apreensão estética, tudo é meticulosamente planejado pelos diferentes setores do entretenimento, pois a indústria cultural usurpa do sujeito justamente aquela capacidade (esquematismo) que, em tese, segundo Kant, de antemão permite-se sair da multiplicidade sensível e chegar aos conceitos fundamentais. Usurpação que seria o primeiro serviço prestado ao cliente. É como se todos possuíssem um "[...] mecanismo secreto destinado a preparar os dados imediatos de modo a se ajustarem ao sistema da razão pura. Mas o segredo está hoje decifrado" (ADORNO; HORKHEIMER, 1985, p. 103).

Esse sequestro do esquematismo associa-se à constituição de um sujeito cuja subjetividade tem sido historicamente enfraquecida em face do mundo objetivo. Semiformado, e com os sentidos atrofiados, aquele se vê impotente para manifestar qualquer resistência com o particular, frente ao que é imposto pelo universal (DUARTE, 2003). Os indivíduos obedecem, assim, a um comportamento mimético, no qual, a partir de esquemas arcaicos de autoconservação, tentam se tornar iguais a seu ambiente, o que explicaria, por exemplo, a patologia coletiva que levou muitos alemães a se perfilarem com os nazistas (DUARTE, 2002). Para darem credibilidade às suas relações com o mundo, os indivíduos tornam-se cada vez mais dependentes dos produtos da indústria cultural, cujo sequestro realizado pelo esquematismo formata a dimensão sensível mediante a atrofia da fantasia, da memória e destituição da espontaneidade. Tudo isso leva à realidade constatada por um estudo empírico desenvolvido no Instituto de Tecnologia de Massachusetts (MIT), cujos dados, publicados na Science em 2018, mostram que as fake news se espalham até $70 \%$ mais rápido que as informações verdadeiras (VOSOUGHI, ROY \& ARAL, 2018).

\section{JORNALISMO, INDÚSTRIA CULTURAL E FAKE NEWS}

A partir do debate que gravita em torno da constituição do conceito de indústria cultural proposto por Adorno e Horkheimer (1985), bem como a caracterização dos objetivos e o modo de operar dessa indústria perante a "formação" da experiência estética de cada um, a grande questão que se conserva, contudo, é qual o papel do jornalismo moderno - historicamente apresentado como um operador 'independente' e 'imparcial' com as funções de instruir a sociedade e vigiar o estado burguês (TRAQUINA, 2012) - dentro desse sistema de domínio ideológico? Ao se tomar a hipótese de que ele é subserviente a essa indústria, seria razoável afirmar que o público sempre fora um leitor de fake news?

Uma análise menos atenta, ainda que estendida à diferentes observações empíricas, poderia delimitar duas respostas antagônicas: ou o jornalismo moderno sempre trabalhou para enganar as massas (o que confirmaria seu enquadramento como agente da indústria cultural e corroboraria a teoria apresentada - a indústria cultural como enganação das massas); ou a atividade jornalística é, de fato, independente e a teoria até aqui defendida estaria equivocada. Porém, em uma perspectiva teórico-crítica, a contradição é a categoria que perfaz a resposta fundada em um exercício dialético. Assim, aqui se 
considera tanto as teorias formuladas para o jornalismo contemporâneo como, por mais relevantes e necessários que sejam os fragmentos, também a totalidade. Isso porque tanto existem veículos jornalísticos que ao longo do último século esforçaram-se no sentido de efetivar as premissas deontológicas da profissão de jornalista, como há aqueles que, em conformidade com o sistema ao qual são subservientes, permitiram a crítica controlada, turva, incapaz de abalar a estrutura dos pilares sobre os quais o próprio jornalismo moderno se sustenta.

Ao considerar que tais contradições são inerentes ao próprio capitalismo, pode-se afirmar que a indústria cultural traz dois objetivos bem definidos, ao transformar a cultura e a notícia em mercadoria. O primeiro é a geração de lucro para os grandes conglomerados dos media, pois sequer haveria interesse por parte dos dirigentes em encobrir essa lógica e o poder fica mais forte quanto mais brutalmente confessam ao público (ADORNO; HORKHEIMER, 1985). Tudo não passa de um grande negócio, uma ideologia utilizada para legitimar o lixo propositalmente produzido (ADORNO; HORKHEIMER, 1985, p. 100).

No caso do jornalismo, há um segundo objetivo implícito, operado por parte considerável dos media: o controle social das massas, pois, destituídas de elementos básicos - crítica, autocrítica, autonomia, emancipação - defendidos pelo movimento Iluminista que fez par com o avanço da modernidade, sufocam a dimensão libertadora da Bildung e, com isso, percebe-se a clara tendência em se legitimar a ordem social hegemonicamente estabelecida sob a égide do modelo capitalista, ao qual a indústria cultural é subserviente.

Ao mesmo tempo em que revela uma condição moral fraca do homem moderno, mostra a situação do trabalhador (o 'homem de ação direta', do romance dostoievskiano). Aparentemente com os ouvidos "livres", os têm tapados e impedidos de experenciar expressões culturais a cujo acesso sua classe social é historicamente excluída. Em analogia à XII Rapsódia da Odisseia, de Homero (ADORNO; HORKHEIMER, 1985), poder-se-ia afirmar que o canto das sereias é a cultura erudita; a cera, que tapa os ouvidos dos remadores, produto da indústria cultural: babitat do jornalismo - braço direito da ideologia burguesa a impelir todos a remarem rumo ao desconhecido, mas impedidos de conhecer (ignorância) os perigos e/ou desfrutar os prazeres do caminho. A contradição faz-se presente. Ora ou outra veículos/indivíduos buscam efetivar a função social do jornalismo, realidade que se mostrou possível nos últimos anos a partir da liberação do polo emissor nas redes sociais online, possibilidade já prevista por Walter Benjamin em $O$ autor como produtor, onde constatou, com alguma melancolia, que "a proletarização do intelectual quase nunca faz dele um proletário" (BENJAMIN, 1994b, p. 135). A reação a essa tentativa de libertação é o convencimento de que a realidade é demasiadamente ruim, o que só é possível argumentar com a mentira.

Nessa perspectiva, surgem as fake news. Seriam elas uma mutação (intencional ou uma espécie de anomalia) do produto jornalístico? Um subproduto da própria indústria cultural, que, apesar de dispor de novos agentes, segue a mesma? Certamente, em outros momentos da história recente, os próprios veículos jornalísticos, em alguma medida desempenharam função semelhante e se aproveitaram da credibilidade da qual dispunham (BORTOLOTTI, 2018). Contudo, por que esse processo se acentuou nos últimos anos e passou a ser reproduzido em larga escala por grupos e indivíduos, que apesar de não deterem a mesma credibilidade pressuposta dos media, atuam como verdadeiros agentes da indústria cultural? A hipótese é de que a liberação da palavra (LEMOS; LÉVY, 2010), associada à regressão dos sentidos - pessoas sociopsicologicamente regredidas, desmedidamente acomodadas porque com egos malformados (ADORNO, 1991; TÜRCKE, 2010) - estimularam tal realidade e condicionaram um novo comportamento mimético de autoconservação.

\section{FILOSOFIA DA SENSAÇÃO: REGRESSÃO DOS SENTIDOS E AS FAKE NEWS}

Uma vez estabelecidas as características que tornam o jornalismo moderno produto (e, ao mesmo tempo, operador) da indústria cultural, destaca-se como o referido conceito é uma potente categoria de análise e compreensão da sociedade contemporânea, cuja referência teórica é o livro Sociedade excitada: filosofia da sensaşão, de Christoph Türcke (2010). De forma paciente e rigorosa, esse autor atualiza as reflexões de Adorno e Horkheimer (1985), em especial as teses sobre a indústria da cultura a partir da 
análise do contexto atual. As diatribes de Türcke ajudam a compreender sobretudo as produções que surgem nas redes sociais online, sejam aquelas de caráter crítico, como o midiativismo e ciberativismo, ou de reforço da semiformação, como as fake news.

Türcke (2010) considera que a sociedade excitada é uma extensão, e não uma superação, da modernidade. Sua principal característica é a ininterrupta produção de mercadorias imagéticas que fomenta o vício no consumo de imagens pela multiplicação exponencial de conteúdos audiovisuais e tende a supersaturar os sentidos, em especial a visão e a audição. Para Türcke (2010, p. 10), o fato de o contexto social ser altamente tecnificado, permitindo que as máquinas sejam menos ofegantes e poluidoras, não significa que a sociedade não seja mais industrial, mas que microeletronicamente ela engana mais facilmente o desejo de seus clientes. Para ele, estaríamos ainda na modernidade, na qual existe entre os indivíduos um deslocamento no significado da palavra sensação, que parte do geral e vai para o particular que reproduz o mesmo movimento que a indústria cultural faz ao se configurar na própria ideologia burguesa disseminada por meio dos seus produtos.

Se em um primeiro momento, a sensação significou nada mais do que percepção, atualmente ela é entendida como aquilo que magneticamente atrai a percepção: o espetacular, o chamativo (TÜRCKE, 2010, p. 9). Ou seja, se antes a sensação era qualquer coisa que se podia perceber, como o sol a esquentar o rosto, atualmente apenas aquilo que é "sensacional", que extrapola a percepção ordinária do dia da dia, a provocar os sentidos ainda que por uma fração de segundos, é considerado digno de ser descrito como "sensação", logo, de "ser percebido"; um valor de importância ímpar na esfera pública burguesa. É a partir desse exercício puramente etimológico e da observação da 'corrida' para produzir estímulos (choques) capazes de provocar a sensação que Türcke (2010) inicia o debate sobre os meios de comunicação de massa. Para ele, se antes sensação conotava perceber, na sociedade atual ela diz respeito ao que atrai, ao que é espetacular. Sensação tornou-se uma espécie de vício, no sentido de desvio do estado sóbrio. Quanto mais choques (o que é estranho, não idêntico) imagéticos, mais preso à compulsão à repetição. O desejo ininterrupto pelo sempre mesmo. Por isso, parte considerável dos indivíduos, na sociedade excitada, é distraída.

No "fazer sensação", os meios de comunicação liberam uma torrente de estímulos que fazem parte daquelas sensações que dificilmente se consegue dominar. Até mesmo o mais distinto intelectual, crítico desses processos, está fechado para tais estímulos. Isso significa que o sentido da sua atenção, os temas e palavras que escolhe, assim como o tempo e o ritmo de seus pensamentos são molestados por eles: "Em curtas palavras, é chegado o momento de se falar de uma sociedade da sensação" (TÜRCKE, 2010, p.10).

Türcke (2010) reconhece que essa mesma sociedade, por ele denominada excitada ou da sensação, de alguma forma teria sido descrita no livro Sociedade do espetáculo (DEBORD, 2003). Contudo, em sua análise, Türcke parte do pressuposto de que a ideologia burguesa é a pele e não o envoltório da estetização da realidade produzida pela indústria cultural, de modo que seria impossível pensá-la de forma dissociada desse sistema. Em sua análise, ele então adiciona a categoria de vício e, por conseguinte, regressão e/ou entorpecimento dos sentidos.

A espetacularização da existência, nessas duas primeiras décadas do século XXI, tem mostrado um efeito mais danoso do que a alienação (já grave e danosa) promovida entre os indivíduos ao longo do capitalismo (TÜRCKE, 2010). Para além de garantir a manutenção do status quo entre a classe trabalhadora, a pressão concorrencial dos media, e consequentemente a multiplicação de estímulos imagéticos em busca da sensação dos indivíduos, tem provocado, segundo o autor, o vício em pílulas audiovisuais - tal diagnóstico pode ser confirmado através de pesquisas como aquela desenvolvida no Programa de Pós-Graduação em Saúde Coletiva da Universidade Federal do Espírito Santo, que revela que 25,3\% dos adolescentes brasileiros são dependentes moderados ou graves de internet (BUENO, 2019). Isso ocorre uma vez que, na busca de provocar sensação nos indivíduos, os mass media produzem conteúdos cada vez mais fragmentados e fugazes, incapazes de representar a totalidade da existência objetiva. Assim como os alucinógenos que prometem alívio momentâneo, mas só reforçam a necessidade do seu consumo, o crescimento exponencial desses conteúdos rasos promete liberdade, mas acaba por se tornar a prisão do indivíduo, que passa a ter seus sentidos supersaturados pelo consumo ininterrupto desses produtos noticiosos da indústria cultural. Logo, acostumados a buscar uma porta de fuga nesse 
material e deseducados de utilizarem os próprios esquemas, os indivíduos passam a necessitar de doses cada vez mais fugazes e sensacionais de estímulo para conseguirem excitar seus sentidos (e isso fisiológica - e não metaforicamente). Ao lembrar a brincadeira com um jornal alemão que tinha a fama de entrevistar cadáveres, Türcke (2010) ilustra que:

\begin{abstract}
Desde o momento que reféns são entrevistados ao vivo, enquanto seus sequestradores apontam um revólver para a sua cabeça, ou desde quando as lágrimas, o gritos e balbucios de feridos de morte ou em estado de choque começaram a entrar live as salas de estar, não se entrevistam, é verdade, cadáveres, mas sim pessoas fadadas a morrer e à beira da morte. Apresentar a morte para um público curioso, mostrando as faces nas quais ela se reflete, e fazendo audíveis as vozes que diante dela tremem, representa um dos excessos mais repugnantes da reportagem moderna. O problema é que não se trata aqui de deslizes, mas de pontos culminantes. A própria associação altamente tecnologizada das mídias leva a isso [...]. Sob condições concorrenciais, a tendência crescente de espetacularização é tão pouco evitável quanto a inovação técnica permanente (TÜRCKE, 2010, p. 13).
\end{abstract}

A partir da mesma alegoria (XII Rapsódia de Homero), discutida por Adorno e Horkheimer (1985), Türcke (2010) lembra que cada um é tão livre de escapar dessa tendência de espetacularização quanto Odisseu era para não sucumbir ao canto das sereias. Assim, ele questiona "[...] como parar uma corrente que atua 24 horas por dia, que não se deixa que reme contra ela [...]?” (TÜRCKE, 2010, p. 14). Uma boa chave de leitura, para ao menos se aproximar da questão, está na ideia de perversão da lógica da notícia. Em sua essência, antes de virar mercadoria, o nome "notícia" só poderia ser dado àquilo que merecesse ser comunicado, que dissesse respeito à res publica (coisa pública). É aí que entraram os gatekeepers: era necessário selecionar quais notícias mereciam ser comunicadas: guerras, violações do estado de direito, catástrofes (TÜRCKE, 2010, p.15). Contudo, a modernidade condicionou o tempo como um denominador mínimo comum: somado aos critérios de noticiabilidade, o hard news tornou-se senhor, pois as notícias deveriam ser novas, atuais, frescas e quentes. Além disso, elas deveriam ser passíveis de compreensão; o que já incluía uma categorização e simplificação muitas vezes perigosa, afinal nada mais bárbaro que transformar vidas em números (ADORNO, 1995). Contudo, isso também não bastou:

Como os números que, de acordo com o contexto no qual são postos, levam a resultados diferentes, o enfático aperto de mão para os fotógrafos pode tanto expressar uma virada política quanto conjurá-la ou simplesmente simulá-la. Que a metamorfose de conteúdos em notícias o mais palpáveis possíveis não se possa dar sem estilização, redução e distorção, é um velho problema das mídias. Normalmente, lida-se com ele no âmbito da ética jornalística [...]. Mas o problema é muito mais profundo (TÜRCKE, 2010, p.17).

Ainda que as notícias sempre tenham sido construídas - o que parece ser difícil questionar -, prevalecia nelas a "primazia do objeto", isso é, ainda que se ornasse, esculpisse e um fato se tornasse espetacular, o seu "caráter explosivo estava garantido de antemão" (TÜRCKE, 2010, p. 17), pois ele só era moldado por ser considerado digno de divulgação: "A ser comunicado, porque importante: eis a lei de base da lógica da notícia" (TÜRCKE, 2010, p. 17). Porém, a pressão concorrencial no decorrer do desenvolvimento da modernidade capitalista levou os diferentes veículos dos media a buscarem uma nova fórmula que garantisse o sucesso em relação aos concorrentes. Ao invés de partir do caráter explosivo dos acontecimentos, passou-se a criar acontecimentos explosivos - "A lei de base da lógica da notícia conduz à sua própria inversão: a ser comunicado porque importante superpõe-se a importante, porque comunicado" (TÜRCKE, 2010, p. 17). Na prática, isso significa que qualquer acontecimento passa a ser relevante a partir do momento que se torna interesse de determinado grupo empresarial do setor, o que provoca uma explosão exponencial na quantidade de conteúdos que podem ser considerados importantes e indispensáveis. Rotular como importante aquilo que divulga é característico da imprensa. Esta deve "[...] inflar o banal, simplificar o complicado, chamar a atenção pública para determinados conteúdos e desviar de outros: isso pertence a ela como a transpiração ao corpo. Ambos exigem uma higiene imperiosa, mas nenhuma higiene os abole" (TÜRCKE, 2010, p. 18). 
Essa inversão no caráter da lógica da notícia, segundo Türcke (2010), manifesta-se de três formas distintas de pressão sobre os produtores (repórteres, apuradores) enquanto operadores da indústria cultural, a saber: 1) como pressão para a escolha imediata (automatizada, acrítica) de pautas que merecem divulgação; 2) como pressão de tornar sua seleção de pautas mais explosiva e interessante que a da concorrência; e 3) como pressão para que suas notícias sejam disparadas ao público de forma que consigam adesão e repercussão. Essa tripla pressão concorrencial é transmitida de forma direta ao público "consumidor" dessas notícias, que na sua vida ordinária passa a adotar o mesmo modus operandi. Para permanecer atualizado e interessante em meio aos demais (com quem julga concorrer), ele precisa submeter seu aparato sensorial à multiplicação de pílulas audiovisuais, cada uma delas composta por um fragmento que não dialoga com os demais e tampouco diz algo sozinho, mas se apresenta como indispensável para o debate construído na esfera pública.

Surge, então, uma relação perigosa: incapaz de constituir uma crítica mais ampla sobre as relações sociais a partir dos media, os indivíduos passam a se formar (ou semiformar) e buscarem alívio em estímulos cada vez mais rasos, haja vista não conseguirem compreender a totalidade. Não obstante, a relação se faz contínua. Quanto mais a pressão concorrencial se acentua, mais se multiplicam os estímulos em busca de sensação (choques) e mais os indivíduos tornam-se viciados e tem seus sentidos supersaturados pela avalanche de mensagens; eles buscam algum protagonismo (ou, ao menos, o não esquecimento) em meio ao coletivo; os acontecimentos precisam ser mais que explosivos, chamativos, como manchetes gritadas. Os meios devem mobilizar "[...] todas as forças específicas de seu gênero e ministrar a notícia com toda a violência de uma injeção multissensorial, de forma que atinja o ponto que almeja: o aparato sensorial ultrassaturado dos contemporâneos" (TÜRCKE, 2010, p. 19).

Acentuam-se, desse modo, os processos, a partir do estabelecimento de um polo emissor supostamente livre (ou, ao menos, mais acessível), marca principal do advento das redes sociais online. Em direção oposta daquela que seria o destino desenhado por Adorno e Horkheimer (1985) a partir de sua crítica à indústria cultural, Lemos e Lévy (2010) consideram que a liberação da palavra permitiu aos indivíduos comunicarem-se de forma mais (ciber)democrática, sem intermediários. A realidade por eles descrita realizou-se em algum grau e conta com importantes espaços de resistência. Contudo, a despeito de iniciativas importantes de midiativismo/ciberativismo (LEMOS; LÉVY, 2010), não se trata de desmerecer as potencialidades da liberação do polo emissor. Ao contrário, a ideia é reconhecer que os obstáculos existem.

A previsão de uma liberdade plena a partir das redes online encontrou oposição nas próprias contradições e nos tradicionais operadores da indústria cultural. Ela esbarra em três características (interpostas e de reforço mútuo) que referendam e agravam o prognóstico feito por Türcke (2010), quais sejam: 1) com a liberação do polo emissor, ocorreu uma multiplicação exponencial dos conteúdos disponíveis (consequentemente, do vício em pílulas audiovisuais), uma vez que todos passaram a ser operadores de um espaço que reproduz a estética da indústria da cultura (basta lembrar que as redes sociais online também são grandes conglomerados dos media, muitas vezes com ações na bolsa de valores); 2) com a manutenção da estética, perseverou também a ética particular aos processos e discursos semiformativos engendrados pela indústria cultural, uma vez que, ainda com o polo emissor liberado, a maior parte desses novos operadores foi e é formada pelos media de massa tradicionais e, por fim, 3) a transferência da lógica da pressão concorrencial para a existência singular de cada um fomentou, em diferentes indivíduos, a inversão da lógica na notícia como premissa da própria vida: se for comunicado, será importante. Por isso, aqui se sugere - como potente via de pesquisa para trabalhos futuros - a hipótese de acordo com a qual é essa transferência (quase mimética) da pressão concorrencial que alimenta as fake news e as tornam uma estratégia aparentemente necessária para o mundo da vida dos diferentes indivíduos.

\section{CONSIDERAÇÕES FINAIS: A EXISTÊNCIA FAKE NA EXCITADA SOCIEDADE DO ESPETÁCULO}

A intenção deste artigo não é delimitar, in totum e de forma definitiva a origem das fake news, tarefa já qualificadamente realizada por autores (DELMAZO; VALENTE, 2018; HÄNSKA; 
BAUCHOWITZ, 2017) que se debruçaram sobre o tema. A produção e circulação de notícias falsas sempre teve lugar cativo, sem exceção, nos principais conglomerados empresariais dos mass media (BORTOLOTTI, 2018). Sua reprodução tem a ver, mas não se reduz à formação semiformada dos sujeitos que prolongam a estética da indústria cultural. Ainda que na configuração de forças ela esteja ligada ao poder do capital, que busca a manutenção do status quo, apenas a identificação das contradições que surgem dessas combinações ajuda a compreender a ampla aceitação das notícias falsas como ethos predominante na sociedade. Nesse sentido, com o objetivo de responder às questões propostas na introdução deste artigo, dá-se destaque a duas hipóteses razoáveis que ajudam a compreender a reprodução acrítica de conteúdos fakes produzidos, divulgados e consumidos nas redes sociais, a partir da contradição do próprio indivíduo moderno frente ao acesso às plataformas online.

A partir da premissa de Adorno e Horkheimer (1985), sobre a existência de uma indústria da cultura que de antemão sequestra o esquematismo dos sujeitos e impõe o universal sobre o particular; e da base teórica apresentada por Adorno (2010), sobre a semiformação dos indivíduos e a supersaturação dos sentidos na sociedade excitada (TÜRCKE, 2010), parece importante diagnosticar que a liberação do polo emissor pressionou os interesses dessa indústria para a existência de cada cidadão cliente, consumidor de seus bens culturais. Os indivíduos tornaram-se "novos" operadores. Contudo, se no âmbito dos media existiam - ainda que nem sempre de forma eficaz - os limites dos critérios de noticiabilidade e da própria ética jornalística que atuava contra a inversão da lógica da notícia, na vida privada, a pressão concorrencial passa a ser regulada por valores mais difusos e abstratos, que podem ser desde concepções religiosas sobre o mundo até uma visão política de determinado evento; desde o mero desejo de ser reconhecido perante o grupo social até a busca de objetivos econômicos. Para tudo isso, passa valer a espetacularização do argumento, que torna a res publica um espaço infinito de produção e divulgação de sofismos e fake news, haja vista que o objetivo é pura e simplesmente tornar seu ponto de vista mais sedutor e vencer seus concorrentes. A questão é que, semiformados, os indivíduos agem intuitivamente, sem refletir sobre as primeiras ou últimas consequências dos seus atos, pura e simplesmente como autopublicidade.

Sobre isso, Türcke (2010) observa que as práticas de publicidade, anteriormente relegadas à ação dos industriais para com os sujeitos, passam a caracterizar o comportamento desses indivíduos, que buscam divulgar a própria vida e o mundo a tentar convertê-los em algo mais sensacional. Tal ponto de vista ajuda a explicar a produção exponencial de mensagens pelos usuários das redes sociais online: ao assimilarem o esquematismo da indústria cultural, as pessoas passam a se considerar parte dela. Assim, o poder muda de caráter, sofre "[...] uma mutação, convertendo-se em uma compulsão social generalizada" (TÜRCKE, 2010, p. 38).

In verbis, uma outra possibilidade de leitura, para se compreender o avanço das fake news, diz respeito ao debate anunciado no início deste artigo: a polêmica relativa ao discurso filosófico da modernidade e a defesa da agenda pós-moderna, pode ser sintetizada no desejo de transpor para a realidade a plenificação da dimensão sensível por meio da estética, que durante séculos foi objeto de conhecimento de uma parcela da classe social hegemônica. No afã de ontologizar a realidade por meio da estética, os autores do pós-moderno partiram para o non sense de um relativismo absoluto que destitui a possibilidade da ética e da verdade, sem as quais se inviabiliza qualquer projeto de democracia fundada na justiça social. Práxis essa que desagua na estetização da vida ordinária (LIPOVETSKY; SERROY, 2015), que, de forma cínica, acata como válido qualquer discurso fundamentado na doxa - opinião tópica, ligeira, sem compromisso com a problematização da realidade, mediada por uma reflexão e autorreflexão críticas.

Ainda que repleta de contradições, paradoxos e disparates, pode-se encontrar um fio de Ariadne a unir os pensadores da agenda pós, cujo imperativo categórico desemboca na ideia de pós-verdade, a fazer par e coro com as fake news. Isso porque, tanto a pós-verdade como as fake news revelam problemas éticos e políticos no mesmo nível e sentido daqueles endógenos à agenda pós-moderna, cujos autores ou negam ou relativizam a verdade. Isso tem implicações até no campo da justiça: afinal, como é possível compreender que qualquer opinião é errada ou qualquer prática injusta, a partir de um dado ponto de vista, sem nenhum padrão exógeno de verdade (NANDA, 1997)? Tratam-se de perguntas necessárias, sobretudo em uma época em que a própria noção de verdade tornou-se irrelevante? 
Poder-se-ia então questionar se por acaso o movimento intelectual fundamentado nas teses da agenda pós desempenhou algum papel no surgimento da pós-verdade e das fake news. Há fortes evidências teóricas que apontam para uma resposta positiva a essa questão. Não por acaso, a crítica literária Michiko Kakutani (2018) afirma que o argumento pós-moderno - todas as verdades são parciais, pois dependem da perspectiva de cada um -, contribui para a ideia de que existem diversas maneiras legítimas de entender ou representar um acontecimento. Isso foi tanto o estopim para a defesa de um discurso mais igualitário, como de igual forma possibilitou escutar a voz dos excluídos, mas também tem sido explorado por haters que equipararam o não equiparável: criacionistas que reivindicam o direito de o design inteligente ser ensinado nas escolas, no mesmo nível que a teoria da evolução das espécies; supremacistas brancos neonazistas reivindicam igualdade de direitos para se manifestarem; negacionistas climáticos, adeptos do movimento antivacina e outros grupos, para quem a ciência para nada serve e disseminam expressões levianas que pouca diferença faz em uma aula sobre a filosofia da desconstrução (Jacques Derrida), pois existem muitos lados, perspectivas diferentes, incertezas e múltiplas formas de conhecimento. Tudo isso contribuiu para que o grande público consumidor (e produtor) das fake news, até certo ponto, não as considerassem uma ameaça (KAKUTANI, 2018).

A era das fake news é também o tempo dos pseudoeventos. Em seu livro The Image, o historiador Daniel Boorstin denomina pseudoeventos aqueles que são planejados, plantados ou incitados principalmente com o escopo imediato de serem reportados ou reproduzidos. Para esse autor, da mesma forma que a imagem passou a substituir os ideais, o conceito de verdade foi substituído por credibilidade (KAKUTANI, 2018). As pessoas pouco se importam em saber se algo é um fato, o que importa é se parece conveniente acreditar nele (KAKUTANI, 2018, p. 100-101). Não por acaso, autores como Jean Baudrillard (1997) defendem que elas preferem o hiper-real - a realidade simulada ou fabricada (vide os parques da Disney) - ao chato e cotidiano deserto do real (KAKUTANI, 2018, p. 102).

Talvez, a tecnologia mais emblemática capaz de exemplificar a voracidade da excitada sociedade do espetáculo seja a World Wide Web. Nela a contradição está implícita, pois tanto permite que os usuários selecionem informações relativas a eventos que podem ser fatos relevantes, ou mesmo factoides (não fatos) que apenas fortalecem a doxa já estabelecida, como pode estimular a criar as condições para que a intelligentsia acadêmica fortaleça suas pesquisas e, do lado oposto, que o senso comum consiga sustentar seus preconceitos sem examinar evidências empíricas para chegar a conclusões racionais. Na Internet, os cliques tendem a ser concebidos como supremos e, mais do que nunca entretenimento e notícias formam uma combinação única. O sensacionalismo, o bizarro, o que causa revolta eleva-se ao topo, "[...] com posts que apelam cinicamente para a parte mais rudimentar de nossos cérebros - para emoções primitivas como medo, ódio e raiva” (KAKUTANI, 2018, p. 151).

É merecedor de nota a aguçada percepção de Debord (2003, p. 11) quando anunciou, em 1967: "No mundo realmente invertido, o verdadeiro é um momento do falso" e, a verdade desta sociedade não é mais do que a sua negação (DEBORD, 2003, p. 127). Vinte e dois anos antes, na Minima Moralia, Adorno (1993) observou que "O todo é o não verdadeiro" (aforismo 29, Frutas anãs), e teceu o seguinte comentário:

\footnotetext{
As coisas chegaram ao ponto em que a mentira soa como verdade e a verdade como mentira. Cada declaração, cada notícia, cada pensamento está preformado pelos centros da indústria cultural. $\mathrm{O}$ que não traz a marca familiar dessa preformação está de antemão destituído de credibilidade, tanto mais que as instituições de opinião pública fazem acompanhar aquilo que divulgam de milhares de comprovações factuais e de toda plausibilidade, de que se pode se apoderar o poder de disposição total. [...] As mentiras têm pernas compridas: elas estão à frente de sua época (ADORNO, 1993, p. 94-95 - aforismo 71, Pseudómenos).
}

Como visto, no decorrer do artigo, Türcke (2010) atualiza a tese de Debord (2003). Ele enfatiza que a sociedade atual continua capitalista, mas conduzida por relações mediadas por imagens espetaculares cujo mercado imagético produz, ininterruptamente, os mesmos choques (nervosos) que criam um ciclo vicioso de excitação, entorpecimento, nova excitação. Eles estão em todas as telas, desde computadores pessoais, tablets, celulares, televisores etc. Longe de preencher apenas o tempo livre, elas invadem a totalidade da vida no mundo do trabalho, de modo a confundir o choque da imagem e a 
ocupação profissional: "O choque da imagem se tornou o foco de um regime global de atenção, que insensibiliza a atenção humana por meio da sobrecarga ininterrupta” (TÜRCKE, 2016, p. 33).

O que fazer para frear/desacelerar esse moto-contínuo? Qual é a alavanca para o freio de emergência? Uma aposta possível é defender a Bildung negativa - como negação determinada da cultura afirmativa que tece loas à excitada sociedade do espetáculo cuja reprodução de uma existência fake passa a ser, também, uma busca pessoal pela semiformação. E a educação escolar pode ser uma grande aliada na aposta da primazia do conhecimento filosófico e científico como forma de duvidar, inquirir a realidade social; valorizar a contradição posta pelas evidências.

A educação é uma das principais apostas da teoria crítica da sociedade, contra toda e qualquer situação de barbárie. A pós-verdade é uma condição política em um contexto de fragilidade social que alimenta a produção e a reprodução da miséria humana e as fake newss são a marca registrada de um permanente estado de exceção. No nível da educação superior, em especial no campo das humanidades, em que acontece a formação dos futuros professores da educação básica, ao menos aqueles que têm oportunidade de acessar uma instituição pública, o triunfo que a racionalidade instrumental capitalista ainda não destruiu por completo, é preciso manter aceso o desejo por igualdade, liberdade, fraternidade (justiça social). A universidade, portanto, pode ser um lócus de resistência àquela lógica. A utopia negativa da teoria crítica pressupõe que a educação formal incorpore a Bildung como experiência capaz de produzir a autonomia do sujeito fundada no conhecimento e valores verdadeiros, válidos e autênticos humanistas - pois contrários à opinião fundada na crença nutrida pelo desespero fomentado pela miséria social engendrada pela dinâmica do capital. A escola e a educação universitária como espaço de criação, produção de um tempo de longa duração que permita formar pessoas aptas para lidarem, de forma crítica e responsável, com as complexidades do Zeitgeist. Isso significa - em termos de projeto educativo incorporar os princípios básicos que regem o conhecimento elaborado, em todos os campos - as artes, literatura, ciências - do saber, mas, principalmente, a atitude filosófica que problematiza, impõe perguntas - por que, como, quando, onde, para que, para quem - pertinentes não apenas aos fenômenos naturais e sociais; mas, principalmente, para que cada um consiga fazer uma autorreflexão crítica. Para isso, não cabe repousar as inquietações aqui levantadas em alguma fórmula ou modelo, mas antes atentar para a necessidade de deixar explícitas as contradições e as condições objetivas que marcam os limites de uma utopia negativa que ainda busca a educação formal como caminho possível frente à vivência ordinária, condicionada pelas fake news dos mass media.

Ao contrário do que sugere o narrador-personagem do romance dostoievskiano citado na abertura deste artigo, não se trata de puro cinismo em prol das ideias abstratas. Há que se considerar, também, que a autorregulamentação e defesa perante a pressão concorrencial da indústria cultural é transportada para o âmbito da vida privada. Semiformados e viciados em doses sempre mais agressivas de choques imagéticos, os indivíduos passam a usar, quase que mimeticamente, das estratégias às quais foram submetidos como forma de defender a própria existência em uma sociedade organizada sob a forma de mercado. Uma tentativa desesperada de adequar e/ou consolar o próprio ego perante o avanço da miséria do espírito humano. A adesão acrítica às fake news, quer seja como consumidores ou produtores, seria muito mais o resultado do crescimento exponencial da sociedade do espetáculo, do que propriamente fruto de uma intencionalidade consciente dos sujeitos.

\section{Agradecimentos}

Agradecemos às professoras Mariana Passos Ramalhete (Língua Portuguesa), Kyria Rebeca Finardi (Inglês) e aos professores Ramón Andrés Ortiz Rojo (Espanhol) e Jorge Luiz do Nascimento (Espanhol) pela revisão atenta e zelosa deste artigo.

\section{REFERÊNCIAS}

ADORNO, Theodor Wiesengrund. O fetichismo na música e a regressão da audição. In: Os Pensadores: Horkheimer e Adorno. São Paulo: Nova Cultural, 1991. p. 77-105. 
ADORNO, Theodor Wiesengrund. Minima Moralia: reflexões a partir da vida danificada. São Paulo: Ática, 1993.

ADORNO, Theodor Wiesengrund. Educação e Emancipação. Rio de Janeiro: Paz e Terra, 1995.

ADORNO, Theodor Wiesengrund. Teoria da semiformação. In: PUCCI, B.; LASTÓRIA, L. A. C. N.; ZUIN, A. A. S. (Orgs.). Teoria crítica e inconformismo: novas perspectivas de pesquisa. Campinas: Autores Associados, 2010, p. 7-40.

ADORNO, Theodor Wiesengrund; HORKHEIMER, Max. Dialética do Esclarecimento: fragmentos filosóficos. Rio de Janeiro: Jorge Zahar Editor, 1985.

ANDERSON, Perry. As origens da pós-modernidade. Rio de Janeiro: Jorge Zahar Editor, 1999.

BANDEIRA, Belkis; OLIVEIRA, Avelino de. Formação cultural e semiformação: contribuições de Theodor Adorno para pensar a educação hoje. Educaşão, Porto Alegre, v. 35, n. 2, p. 225-232, mai./ago. 2012.

BAUDRILLARD, Jean. Simulacros e simulações. Lisboa: Relógio D’água, 1991.

BAUDRILLARD, Jean. O crime perfeito. Lisboa: Relógio D’Água Editores, 1996.

BAUDRILLARD, Jean. A Disney World ilimitada. Folha de São Paulo, Caderno Mais!, 9.02.1997. Disponível em: https://www1.folha.uol.com.br/fsp/1997/2/09/mais!/3.html. Acesso em: 25.06.1997.

BENJAMIN, Walter. Experiência e pobreza. In: . Magia e técnica, arte e política: ensaios sobre literatura e história da cultura. 7. ed. São Paulo: Brasiliense, 1994a, p. 114-119.

BENJAMIN, Walter. O autor como produtor. In: - Magia e técnica, arte e politica: ensaios sobre literatura e história da cultura. 7. ed. São Paulo: Brasiliense, 1994b, p. 120-136.

BOHLIN, Henrik. Bildung and intercultural understanding. Intercultural education, London, v. 24, n. 25, p. 391-400, 2013. Disponível em: https://dokumen.tips/documents/bildung-and-interculturalunderstanding.html. Acesso em: 05.07.2018.

BORTOLOTTI, Plínio. Mentira não é jornalismo. In: FILGUEIRAS, Isabel et. al. Jornalismo em tempos de pós-verdade. Fortaleza: Dummar, 2018, p. 280-566 [ebook].

BUENO, George Nunes. Acesso à internet e às mídias sociais e sua relação com os fatores de risco para doenças e agravos em adolescentes de 15 a 19 anos na Região Metropolitana da Grande Vitória/ES. Tese apresentada ao programa de Pós-Graduação em Saúde Coletiva da Universidade Federal do Espírito Santo, 2019.

CHAUÍ, Marilena. Convite à Filosofia. São Paulo: Ática, 2000.

DEBORD, Guy. A sociedade do espetáculo: comentários sobre a sociedade do espetáculo. Rio de Janeiro: Contraponto, 2003.

DELMAZO, Caroline; VALENTE, Jonas C. L. Fake news nas redes sociais online: propagação e reações à desinformação em busca de cliques. Media e Jornalismo, Imprensa da Universidade de Coimbra, Coimbra University Press, n. 32, vol. 18, 2018. Disponível em: http://www.scielo.mec.pt/scielo.php?script=sci_arttext\&pid=S2183-54622018000100012. Acesso em: 26.06.2019.

DENTZ, Volmir Von. As tendências pós-críticas na pesquisa em educação: análise filosófica e crítica ontológica. Tese apresentada ao Programa de Pós-Graduação em Educação na Universidade Estadual de Campinhas, 2015.

DOSTOIÉVSKI, Fiódor. Notas do subsolo. Porto Alegre: L\&PM, 2018.

DUARTE, Rodrigo. Adorno/Horkheimer e a Dialética do esclarecimento. Rio de Janeiro: Jorge Zahar Editor, 2002. 
DUARTE, Rodrigo. Esquematismo e semiformação. Educação e Sociedade, Campinas, vol. 24, n. 83, p. 441-457, 2003.

EAGLETON, Terry. A ideologia da estética. Rio de Janeiro: Jorge Zahar, 1993.

EAGLETON, Terry. De onde vêm os pós-modernistas? In: WOOD, Ellen Meiksins. \& FOSTER, J.B. (Org.). Em defesa da bistória. Rio de Janeiro: Jorge Zahar, 1999. p. 23-32.

FLICKINGER, Hans-Gyorg. Herança e futuro do conceito de formação. Educação e Sociedade, Campinas, v. $32, \quad$ n. $117, \quad$ p. 151-167, jan./mar. 2011. Disponível em: www.scielo.br/pdf/es/v32n114/a10v32n114.pdf. Acesso em: 05.05. 2012.

GONÇALVES, Etiene do Nascimento; BORBA, Siomara. Elementos par ao debate curricular contemporâneo: Richard Rorty e a contribuição do Neopragmatismo. Currículo sem Fronteiras, v. 9., n. 22, pp. 11-31, jul./dez. 2009. Disponível em: www.curriculosemfronteiras.org. Acesso em: 25.05.2019.

GRENZ, Stanley. Pós-modernismo: um guia para entender a filosofia de nosso tempo. São Paulo: Vida Nova, 2008.

HABERMAS, Jürgen. O discurso filosófico da modernidade. 3. ed. Lisboa: Dom Quixote, 2000.

HÄNSKA, Max; BAUCHOWITZ, Stefan. Title Tweeting for Brexit: how social media influenced the referendum. In: MAIR, John; CLARK, Tor; FOWLER, Neil; SNODDY, Raymond; TAIT, Richard (eds.). Brexit, Trump and the Media. Reino Unido: Ed. Acadêmica Abramis, 2017, p. 31-35. Disponível em: http://eprints.lse.ac.uk/84614/. Acesso em: 25.05.2018.

HARSIN, Jason. Post-Truth and critical communication. Texas: Oxford University Press, 2018. Disponível em: www.researchgate.net/publication/327289246. Acesso em: 20.04.2019.

KAKUTANI, Michiko. A morte da verdade: notas sobre a mentira na Era Trump. Tradução de André Cazrnobai e Marcela Duarte. Rio de Janeiro: Intrínseca, 2018.

LEMOS, André; LÉVY, Pierre. O futuro da internet. em direção a uma ciberdemocracia planetária. São Paulo: Paulus, 2010.

LOPES, Alice Casemiro. Teorias pós-críticas, política e currículo. Educação, Sociedade e Culturas, n. 39, p. 7-23, 2013. Disponível em: https://docplayer.com.br/6324136-Teorias-pos-criticas-politica-ecurriculo.html. Acesso em: 25.06.2019.

LYOTARD, Jean-François. A condição pós-moderna. 12. ed. Rio de Janeiro: José Olympio, 2000.

LYOTARD, Jean-François. Answering the question: what is postmodernism? In: DOCHERTY, T. (Org.). Postmodernism: a reader. London/New York: Routledge, 2014a, p. 38-47.

LYOTARD, Jean-François. Notes on the meaning of post. In: DOCHERTY, T. (Org.). Postmodernism: a reader. London/New York: Routledge, 2014b, p. 47-50.

LIPOVETSKY, Gilles; SERROY, Jean. A estetização do mundo: viver na era do capitalismo artista. São Paulo: Companhia das Letras, 2015.

MÁRQUEZ, Gabriel García. O outono do patriarca. Rio de Janeiro: Record, 1976.

MORAES, Maria Célia Marcondes de. O renovado conservadorismo da agenda pós-moderna. Cadernos de Pesquisa, São Paulo. v. 34, n. 122, p. 337-357, mai./ago. 2004.

MORAES, M. C. M. de. Os "pós-ismos" e outras querelas ideológicas. Perspectiva, Florianópolis: UFSC/CED, NUP, n. 24, p. 45-59, jan./jun. 1996.

NANDA, Meera. Restoring the real: rethinking social constructivist theories of Science. In: The Socialist Register. PANITCH, L. (ed.). London: Merlin Press, 1997. Disponível em: https://socialistregister.com/index.php/srv/article/view/5694/2591. Acesso em: 23.06.2019. 
NIETZSCHE, Friedrich. Escritos sobre educação: Friedrich Nietzsche. São Paulo: Edições Loyola/ Rio de Janeiro: Editora PUC-Rio, 2003.

OXFORD DICTIONARIES. Word of the Year 2016 Is... Disponível em: https://languages.oup.com/word-of-the-year/word-of-the-year-2016. Acessado em 24.06.2019.

POMPEU, Ana. Mamadeira erótica de Haddad - a fake news que viralizou nas redes sociais. Pragmatismo Político. 05.10.2018. Disponível em: https://www.pragmatismopolitico.com.br/2018/10/mamadeiraerotica-de-haddad-fake-news.html. Acesso em: 22.06.2019.

RAMOS-de-OLIVEIRA, Newton. Reflexões sobre a vida danificada. In: ZUIN, A.A.S. (Org.). A educação danificada: contribuições à teoria crítica da educação. 2. ed. Petrópolis/Vozes; São Caros/UFSCar, 1998, p. 13-44.

REITTER, Paul; WELLMON, Chad. Anti-education: Friedrich Nietzsche - on the future of our educational institutions. New York: New York Rewiew Books, 2016.

RORTY, Richard. Ensaio sobre Heidegger e outros. Lisboa: Instituto Piaget, 1999.

RORTY, Richard. A filosofia e o espelho da natureza. Rio de Janeiro: Relume-Dumará, 1994.

RUSCHEL, Maria Helena. Glossário. In: ADORNO, T. W. Palavras e sinais: modelos críticos 2. Petrópolis: Vozes, 1995. p. 237-253.

SEVERINO, Antônio Joaquim. A filosofia da educação no Brasil: esboço de uma trajetória. In: GHIRALDELLI JR., Paulo. (Org.). O que é filosofia da educação? Rio de Janeiro: DP\&A, 1999. p. 267-328.

SCHILLER, Friedrich. Sobre a educação estética do ser humano numa série de cartas e outros textos. Rio de Janeiro: Imprensa Nacional, Casa da Moeda, 1994.

SOKAL, Alan; BRICMONT, Jean. Imposturas intelectuais. Rio de Janeiro: Record, 1999.

TRAQUINA, Nelson. Teorias do Jornalismo: porque as notícias são como são. Florianópolis: Insular, v. 1, 2012.

SUAREZ, Rosana. Nota sobre o conceito de Bildung (formação cultural). Kriterion, Belo Horizonte, $\mathrm{n}^{\circ}$ 112, Dez/2005, p. 191-198. Disponível em: http://dx.doi.org/10.1590/S0100-512X2005000200005. Acesso em: 05.05.2019.

TÜRCKE, Christoph. Sociedade excitada: filosofia da sensação. Campinas: Editora da Unicamp, 2010.

TÜRCKE, Christoph. Hiperativos! Abaixo a cultura do déficit de atenção. Rio de Janeiro/São Paulo: Paz \& Terra, 2016.

VOSOUGHI, S.; ROY, D.; ARAL, S. The spread of true and false news online. Science, v. 359, p. 11461151, 2018.

WEBER, José Fernandes. Bildung e educação. Educação e Realidade, Porto Alegre, UFRGS, 31(2), p. $117-$ 134, jul./dez. 2006. Disponível em: <https://www.redalyc.org/html/3172/317227044008/>. Acesso em: 30.07.2018.

WOOD, Ellen Meiksins. Em defesa da História: o marxismo e a agenda pós-moderna. Crítica Marxista, São Paulo, Brasiliense, v.1, n.3, 1996, p.118-127.

ZUIN, Antônio Álvaro Soares; GOMES, Luiz Roberto. A formação da subjetividade na Idade Mídia. Revista Eletrônica de Educação, UFSCar, v. 13, n. 2, p. 377-387, mai./ago. 2019. Disponível em: http://www.reveduc.ufscar.br/index.php/reveduc/article/view/3350/828. Acesso em: 25.06.2019.

ZUIN, Antônio Álvaro Soares; ZUIN, Vania G. A atualidade do conceito de semiformação e o renascimento da Bildung. Espaço Pedagógico, v. 24, n. 3, Passo Fundo, p. 420-436, set./dez. 2017. Disponível em: <www.upf.br/seer/index.php/rep>. Acesso em: 15.05.2018. 
ZUIN, Antônio Álvaro Soares. Sobre a atualidade do conceito de Indústria Cultural. Cad. CEDES [online]. Campinhas (SP), 2001, vol. 21, n. 54, pp. 9-18. Disponível: http://dx.doi.org/10.1590/S010132622001000200002. Acesso em: 10.05.2019.

Submetido: 06/08/2019

Aprovado: $17 / 05 / 2020$ 